\title{
White muscle disease in foals: focus on selenium soil content. A case series
}

\author{
Catherine Delesalle ${ }^{1 *}$ (D) Marco de Bruijn ${ }^{2}$, Sanne Wilmink ${ }^{2,3}$, Hilde Vandendriessche ${ }^{4}$, Gerben Mol ${ }^{5}$, \\ Berit Boshuizen ${ }^{1,2}$, Lukas Plancke ${ }^{1}$ and Guy Grinwis ${ }^{6}$
}

\begin{abstract}
Background: White muscle disease (WMD) is a nutritional myopathy caused by selenium (Se) deficiency. In most soils, Se is present in low concentrations, sometimes even below $0.2 \mathrm{mg} / \mathrm{kg}$, a trend which is seen in many countries. Apart from total soil Se concentrations, soil conditions may be such that the bio-availability of Se is so low that it causes very low uptake in plants which can ultimately lead to deficiency problems in animals. This is the first case series to report clinical WMD in foals in areas deficient in Se, in the Netherlands.

The aim of the current report is to provide an overview of the clinical history, symptoms and (clinical) pathology of 8 newborn foals living at 4 different premises and suffering from WMD together with the effectiveness of Se and vitamin E (Vit E) supplementation in the affected foals, their dams and herd members. Hands on practical information is provided to apply a correct and effective Se supplementation management in horses and which pitfalls need to be avoided for a successful approach.
\end{abstract}

Case presentation: Case features and history were mapped out for all foals. Se and Vit E status were assessed for the foals, their dams and herd members, at admission and after 3 months of Vit E/Se supplementation. Common symptoms were muscle weakness, inability to rise, lethargy and inadequate suckle reflex together with increased serum muscle enzymes and low glutathione peroxidase (GSH-Px) and low to normal serum vit E levels. Necropsy revealed necrosis of skeletal muscles consistent with nutritional myopathy. Se status of the dams and herd members correlated well with the Se status of the foals. All surviving foals $(n=6)$ showed normal Vit $E$ and GSH-Px levels after supplementation, likewise, all horses tested at premises 1, 3 and 4. However, dams and herd members in premises 2 showed no normalization. Horses of that premises were diagnosed with pyrrolizidine intoxication one year prior to the study.

Conclusions: Certain regions in the Netherlands are sufficiently Se deficient to predispose newborn foals to develop WMD, especially when they are being fed a diet that mainly consists of locally harvested roughage.

Keywords: Selenium, Vitamin E, Liver disease, Nutritional myopathy, Soil analysis

\section{Background}

White muscle disease (WMD) is a peracute to subacute nutritional myopathy affecting both skeletal and cardiac muscles and is caused primarily by Se deficiency and to a lesser extend Vit E deficiency [1, 2]. It is reported in various animal species, including the horse, in which mainly foals are affected up to weanling age, though adult cases have been described occasionally as well,

\footnotetext{
* Correspondence: Catherine.Delesalle@UGent.be

'Department of Comparative Physiology and Biometrics, Faculty of Veterinary Medicine, Ghent University, Ghent, Belgium

Full list of author information is available at the end of the article
}

with $82 \%$ of confirmed cases aged below four years [3-12]. The underlying pathology is thought to be free-radical mediated rhabdomyolysis. Both Se and Vit $\mathrm{E}$ have an important antioxidant function and protect cell membranes against damage due to free radicals [13]. Se is an important, redox-sensitive element and is a constituent of GSH-Px, which is essential to neutralize reactive oxygen species produced during oxidation of unsaturated fatty acids. Se forms hydroxy fatty acids which are soluble and can be broken down by beta-oxidation. Vit $\mathrm{E}$ is important to prevent transition of fatty acids into peroxides, however, unlike Se, it can't form soluble hydroxy fatty acids. Typically occurrence of WMD cases is geographically restricted to areas of low 
soil Se content. However not all foals low in serum Se and Vit E levels develop the disease, which suggests that individual factors (such as exercise load and other stressors) are also of importance in pathogenesis of the disease.

Mortality of WMD is high, both in foals and horses, ranging from $30 \%$ to $45 \%[5,6,14,15]$. Nutritional myodegeneration manifests as either a peracute form, where death due to cardiovascular collapse and pulmonary oedema occurs within hours; or more commonly, a subacute form where marked progressive muscular weakness and associated metabolic derangements (including hyperkalemia, hyponatremia, hypocalcemia, hypochloremia) generate a variety of clinical signs $[6,12]$, ranging from sudden recumbency, tachypnea, dyspnea and arrhythmias in the peracute form, to inability to stand, weakness, dysphagia, trismus and muscle fasciculations in the subacute form. In young foals these presenting signs must be differentiated from other potentially fatal conditions, such as septicaemia, neonatal asphyxia, pneumonia, botulism, tetanus, trauma or septic arthritis. Clinical pathology findings are consistent with a myopathy and the diagnosis of a nutritional myopathy can be supported by low serum gluthatione-peroxidase (GSHPx) and Vit E levels [5, 6, 16]. At necropsy, affected muscle groups appear pale or exhibit pale striations. Since muscular exercise results in an increased production of free radicals and other forms of reactive oxygen species, muscles with high physiological motion activity such as the diaphragm, intercostal muscles, gluteal muscles, the tongue, masticatory muscles and the myocardium are usually most severely affected. These muscle groups typically have a high percentage of type 1 or red fibres. Histopathology reveals polyphasic and polyfocal degeneration and necrosis with hyalinization, fragmentation and mineralization of myofibres [17].

Se becomes more and more insufficient in food crops as a result of the increasing intensive plant production in many countries [18]. On top of that there is the problem of acid rain that reduces Se bioavailability. Effective recycling of selenium is challenging. Selenium is added in some commercial fertilizers, however, only a small fraction is taken up by plants, leaving much of the remainder to be lost for future utilization [19]. Therefore, problems associated with Se deficiency manifest themselves with increasing frequency and this trend is expected to continue [18-21].

Adequate Vitamin E and Se intake in mares in gestation is known to prevent WMD in newborn foals $[1,6$, 22]. Se uptake in the foal mainly occurs via the placenta during gestation, whereas Vitamin E uptake occurs after birth during uptake of the colostrum. So uptake of Vit E and Se greatly depends upon Se and Vit E status of the dam $[1,23,24]$. Therefore pastures and fields growing fodder crops should be balanced in soil nutrient content, with special attention for Se content, in order to guarantee appropriate Se uptake by the fetus.

Breeding farms and farms specialized in rearing of young foals localised in Se deficient areas that provide a diet mainly consisting of roughage to their horses should be extra cautious. Unbalanced liming and fertilization conditions may further predispose their horses to health problems associated with insufficient Se uptake. Allaway [25] has suggested that it is desirable to control the Se levels in food and feed crops to a range between 0.1-1 ppm. In her extensive review on Se deficiency and toxicity Fordyce [26] suggests that Se levels in feed crops should go above $0.1 \mathrm{mg} \mathrm{kg}^{-1}$ and should not exceed $3-5 \mathrm{mg} \mathrm{kg}^{-1}$.

Little is known about how exactly Se is taken up by the horse via the oral route. Studies have shown that dietary Se supplementation, both through organic (selenomethioinin, e.g. through Se-enriched yeasts) and inorganic (selenite: $\mathrm{SeO}_{3}^{2-}$ ) supplements,elevates plasma or serum and muscle Se status [22, 23]. Adequate Vitamin $\mathrm{E}$ uptake by the mare and subsequent redistribution to the colostrum requires appropriate intestinal absorption and liver function [2, 27]. Hepatic function can be chronically reduced as a result of progressive liver cirrhosis, a common consequence of ragwort poisoning in the horse [28].

This is the first case series to report clinical WMD in foals in areas deficient in Se in the Netherlands and providing geological insight into possible preventive management measures. Effectiveness of $\mathrm{Se}$ and Vit $\mathrm{E}$ supplementation in these foals, their dams and herd members was monitored and deemed ineffective in adults of one herd formerly diagnosed with pyrollizidine intoxication based upon confirmed uptake of roughage contaminated with ragwort and increased blood liver enzymes. The soil content overviews are provided on geographical maps both for The Netherlands and Belgium (Figs. 1 \& 2).

\section{Case presentation}

Eight newborn foals living at 4 different premises (premises 1: cases 1 to 3, including follow up of Se and Vit E status of the respective dams and 4 herd members; premises 2: cases 4 to 6 , respective dams and 7 herd members; premises 3: case 7; premises 4: case 8). Case features, history and clinical findings in the foals are summarised in Table 1. Figure 1 provides a geographical overview of total (panel A) and available (panel B) Se soil content in The Netherlands, together with the location of the four premises included in this case series. Clinical pathology at the time of admission in the foals and their respective dams are presented in Table 2. Increased muscle enzymes (CPK, SGOT and LDH) were found in all cases tested. Treatment of the foals upon admission encompassed plasma transfusion, infusion with normal saline, $20 \mathrm{mg} / \mathrm{kg}$ q24 IV amikacin ${ }^{1}, 25 \mathrm{mg} / \mathrm{kg}$ q12 IV 


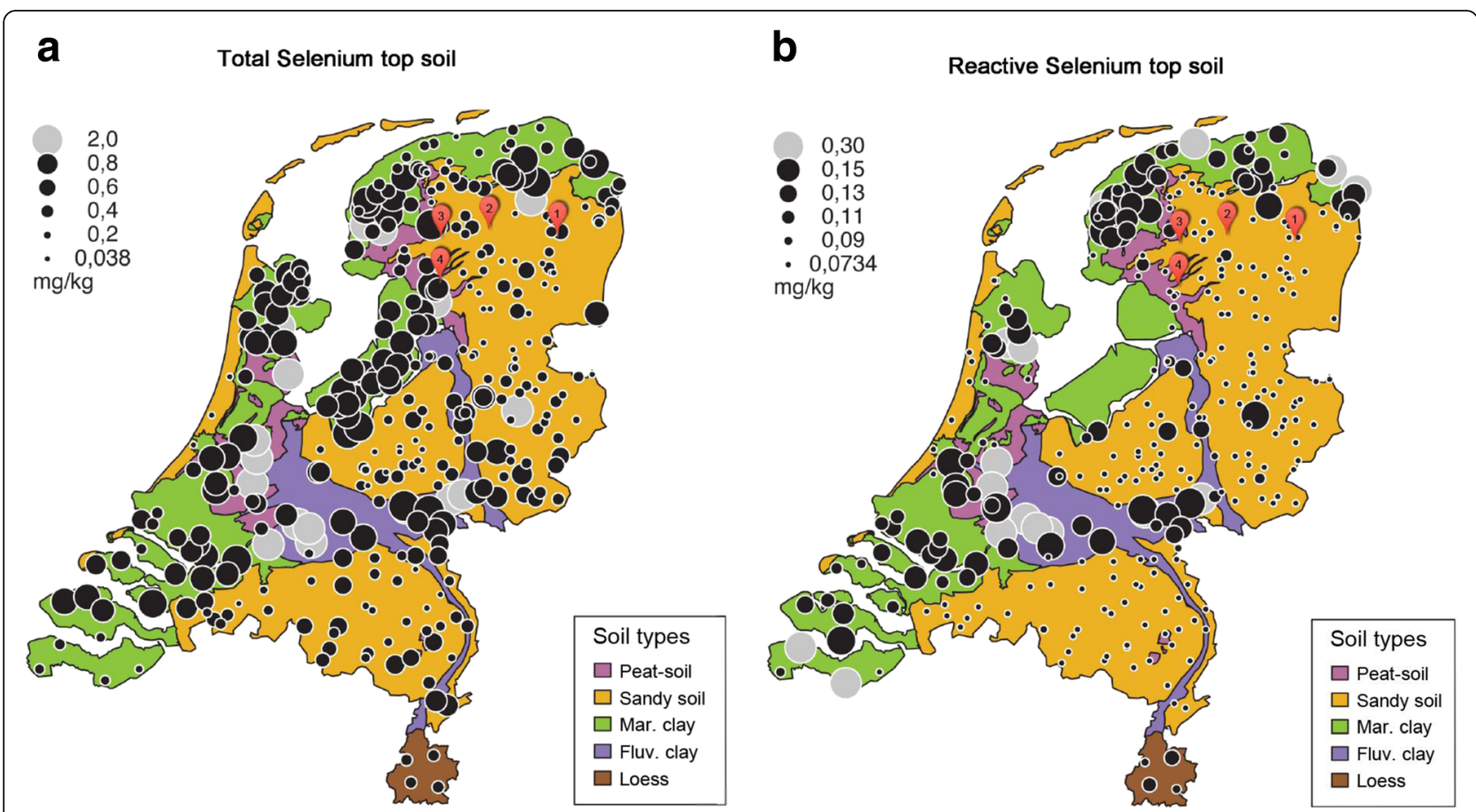

Fig. 1 Geographical overview of Se content in the Netherlands. Notice that all four premises with affected foals are indeed located in Se deficient areas. Panel a: Results on top soil $(0-20 \mathrm{~cm})$ on 358 locations in forests, agricultural and natural areas, representing total Se content. Panel $\mathbf{b}$ : representing "maximum available Se content" (analysis with ICP-MS after $0.43 \mathrm{HNO}_{3}$ extraction). Mark the important difference between "total" and "maximum available" Se content. The grey circles indicate the locations with Se concentrations exceeding the 95 percentile. Reprinted from Mol et al. [34]

ampicillin $^{2}, 600 \mu \mathrm{g} / \mathrm{kg}$ q24 PO meloxicam ${ }^{3}$, and $4 \mathrm{mg} / \mathrm{kg}$ q24 PO omeprazol ${ }^{4}$. Also, these foals were manually supported to enable nursing at the mare. The foals in cases 3 to 8 received an injection of $250 \mathrm{mg}$ Vit $\mathrm{E}$ and $7.5 \mathrm{mg} \mathrm{Se}$ on the day of admission. All foals, dams and herd members were orally supplemented with $2 \mathrm{mg} / \mathrm{kg}$ Vit E and $5 \mu \mathrm{g} / \mathrm{kg}$ $\mathrm{Se}$ (as sodium selenite: $\left.\mathrm{Na}_{2} \mathrm{SeO}_{3}\right)^{6}$ during three consecutive months.

\section{Outcome}

Cases 2 and 5 did not survive. Case 2 gradually became lethargic and due to complete absence of a suckling reflex, the owner opted for euthanasia 2 days after admission. Case 5 died four hours after admission. All other foals survived. Their suckle reflex improved and they regained strength over a period of days. However, it took more than 3 weeks before foal 7 eventually was able to rise by itself.

\section{Post mortem findings}

Post mortem findings were available for the two nonsurviving cases (case 2 and 5) and histopathological examination of respectively the iliopsoas and semimembranosus muscle revealed findings consistent with WMD.

The case 2 foal was found to have its gastro-intestinal tract poorly filled with ingesta, and the left iliopsoas muscle was markedly pale. The lungs were hyperaemic with mild pulmonary oedema. In both the alveoli and bronchioles a protein-rich fluid containing fibrin, erythrocytes, PMK's and skin scabs was found, suggestive of aspiration of amniotic fluid possibly due to intra-uterine asphyxia. The left major psoas muscle showed swelling of muscle fibres, loss of cross striation and fragmentation of many myofibres, focal mineralization of affected muscle fibres, karyorrhexis and karyolysis consistent with WMD.

Samples of heart muscle and semimembranosus muscle of case 5 were submitted for histopathological evaluation. Diffusely in the semimembranosus muscle the muscle fibres were hypereosinophilic, fragmented, vacuolated and showed loss of cross striation with influx of macrophages and hypertrophy of satellite cells. A small number of muscle fibres retained some striation and showed increased basophilia and centrally localised nuclei, suggestive of regeneration. The diffuse severe polyphasic degeneration and necrosis of the muscle fibres is consistent with WMD (Figure 3).

\section{Follow up}

GSH-Px and Vit E values for the foals of premises 1 and 2, their dams and herd members at the time of admission and after three months of oral supplementation are depicted in Tables 3 and 4. The results of the analysis of the locally sourced grass and hay fed to the horses in premises 2 is provided in Table 5. Blood GSH-Px 


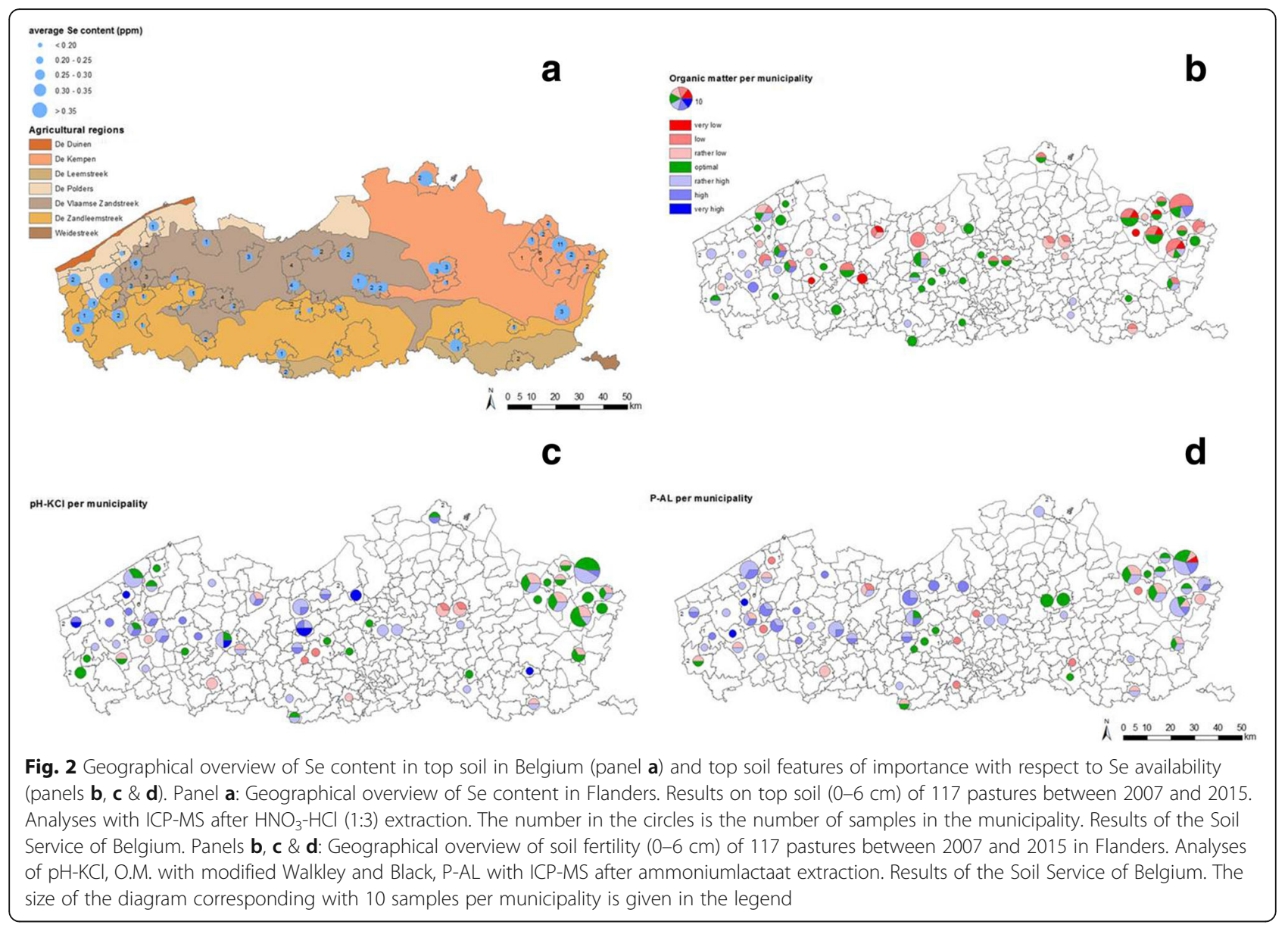

values improved after three months of supplementation in premises 1 , however, no improvement was recorded in premises 2 . Table 4 shows the blood results of 10 mares at premises 2 after a prolonged period of vitamin $\mathrm{E}$ and $\mathrm{Se}$ supplementation. 7/10 and 6/10 mares showed Se and Vit E deficiency respectively despite prolonged supplementation. These horses had a previous history of liver disease due to ragwort (pyrrolizidine) poisoning.
The results of the analysis of the roughage (Table 5) indicate that the mares from premises 2 were fed a $\mathrm{Se}$ deficient diet.

\section{Discussion}

This case series shows that WMD in foals is a relevant disease in the Netherlands and that more attention needs to be paid to soil Se status, and soil $\mathrm{pH}$ and organic matter content in any geographical region that is

Table 1 Case details of the foals

\begin{tabular}{|c|c|c|c|c|c|c|c|c|}
\hline & Case 1 & Case 2 & Case 3 & Case 4 & Case 5 & Case 6 & Case 7 & Case 8 \\
\hline $\begin{array}{l}\text { Year } \\
\text { presented }\end{array}$ & 2007 & 2009 & 2010 & 2010 & 2011 & 2012 & 2011 & 2011 \\
\hline Age of foal & 1 day & $12 \mathrm{~h}$ & $3 \mathrm{~h}$ & 1 week & $36 \mathrm{~h}$ & $12 \mathrm{~h}$ & 1 day & $1 \mathrm{~h}$ \\
\hline Behaviour & Depressed & $\begin{array}{l}\text { Dull, uncontrolled } \\
\text { movements }\end{array}$ & Bright & Bright & Dull & Bright & Dull & Bright \\
\hline $\begin{array}{l}\text { Muscle } \\
\text { weakness }\end{array}$ & $\begin{array}{l}\text { Not } \\
\text { noticed }\end{array}$ & Not noticed & None & $\begin{array}{l}\text { Sternal recumb, unable to } \\
\text { remain standing }\end{array}$ & $\begin{array}{l}\text { Lateral } \\
\text { recumb }\end{array}$ & $\begin{array}{l}\text { Unable } \\
\text { to rise }\end{array}$ & $\begin{array}{l}\text { Unable } \\
\text { to rise }\end{array}$ & Not noticed \\
\hline Suckling & $\begin{array}{l}\text { Reflex } \\
\text { absent }\end{array}$ & Reflex absent & $\begin{array}{l}\text { Reflex } \\
\text { absent }\end{array}$ & Normal & Normal & Normal & Normal & Normal \\
\hline Gestation & \multicolumn{8}{|c|}{ Normal length (reference: $320-360$ days [55]), no adverse events (illness, premature milk production, ...) } \\
\hline Parturition & Normal & $\begin{array}{l}\text { Normal, bleeding } \\
\text { from umbilicus }\end{array}$ & Normal & Normal & Normal & Normal & Normal & $\begin{array}{l}\text { Mare rectum prolapse, } \\
\text { foal normal. }\end{array}$ \\
\hline
\end{tabular}


Table 2 Blood values of foals on or shortly after presentation in hospital and GSH-Px and Vit E values of their respective dams

\begin{tabular}{|c|c|c|c|c|c|c|c|c|c|}
\hline & $\begin{array}{l}\text { Case } 1 \\
2007\end{array}$ & $\begin{array}{l}\text { Case } 2 \\
2009\end{array}$ & $\begin{array}{l}\text { Case } 3 \\
2010\end{array}$ & $\begin{array}{l}\text { Case } 4 \\
2010 \\
\end{array}$ & $\begin{array}{l}\text { Case } 5 \\
2011 \\
\end{array}$ & Case 62012 & $\begin{array}{l}\text { Case } 7 \\
2011 \\
\end{array}$ & $\begin{array}{l}\text { Case } 8 \\
2011 \\
\end{array}$ & Reference values \\
\hline Hematocrit (\%) & 43 & 52 & 42 & 27 & 35 & .38 & 40 & 25 & $32-52$ \\
\hline WBC $(g / L)$ & 11.7 & 18 & 7.3 & 11.1 & 0.4 & 4.4 & 6.8 & 10.6 & $5.5-12.5$ \\
\hline Electrolytes & $\dagger$ & * & $\dagger$ & * & $K>9$ & * & t & * & $\circ$ \\
\hline Blood gasses & $\dagger$ & * & $\dagger$ & * & $\mathrm{pH} 7.2$ & * & $\dagger$ & * & $\circ$ \\
\hline Urea (mmol/L) & 12.7 & 12.1 & 6.2 & 11.5 & $\dagger$ & 4.4 & 2.9 & 3.5 & $0-9$ \\
\hline Creatinine $(\mu \mathrm{mol} / \mathrm{L})$ & * & 518 & 250 & 44 & $\dagger$ & 95 & 93 & 79 & $116-180$ \\
\hline GOT (IU/L) & * & * & 82 & 6000 & 5960 & 4340 & 17,500 & 9120 & $22-488$ \\
\hline CPK (IU/L) & * & * & 710 & 33,300 & 172,800 & 39,700 & 137,300 & 95,400 & $0-269$ \\
\hline $\mathrm{LDH}(\mathrm{IU} / \mathrm{L})$ & * & * & 1128 & 1678 & 51,000 & 14,100 & 83,000 & 52,600 & $162-412$ \\
\hline $\lg G(g / L)$ & * & * & * & $<4$ & * & $*$ & * & $4-8$ & $>8$ \\
\hline $\begin{array}{l}\text { GSH-Px } \\
(\mathrm{U} / \mathrm{g} \mathrm{Hb})\end{array}$ & * & * & 43 & 22 & * & * & 12 & 11 & $>120 \neq$ \\
\hline Vit $E(\mu \mathrm{mol} / \mathrm{L})$ & * & * & 8.7 & 2.0 & * & 6.4 & 6,2 & 6.1 & $\S$ \\
\hline GSH-Px (U/g Hb) & * & * & 59 & 9 & * & * & $<10$ & 16 & $>120 \neq$ \\
\hline Vit E ( $\mu \mathrm{mol} / \mathrm{L})$ & * & * & 6.3 & 3.8 & * & 4.0 & 6,4 & 8.8 & $\S$ \\
\hline
\end{tabular}

* not tested

$\dagger$ all within reference values

${ }^{\circ}$ References (mEq/L): Na (132-146), K (2.4-4.7), Cl (99-109), Ca (1.4-1.7) [56] ${ }^{\circ}$ References: bicarbonate (20-28 mmol/L), pH (7.32-7.44) [56]

\# reference values for the laboratory used in case 4: 120-300, reference values the laboratory used in case 5, 6 and 8: 120-500

$\S$ reference values for the laboratory used in case $4:>7,4$, reference values the laboratory used in case $5,6,7$ and $8:>4,0$

known to have Se deficient soil. Indeed, it is important that Se fertilization receives proper attention. In most soils, Se is present in very low concentrations, sometimes even below $0.2 \mathrm{mg} / \mathrm{kg}$. Even when total concentrations in soil seem adequate, soil conditions may be such that the bio-availability of Se is so low that it causes very low uptake in plants which can ultimately lead to deficiency problems in animals. A problem which will manifest itself most probably with increasing prevalence in the future [18-21]. See Figs. $1 \& 2$ for an overview of the relation between soil types and Se availability in The Netherlands (Fig. 1) and Belgium (Figure 2) and note the important differences between total Se (Fig. 1, panel a) and maximum available Se (Fig. 1, panel b) content in the top soil.

Important to notice: in acid and neutral soils, Se availability is suppressed because Se is mostly present as selenite which may be fixed and highly insoluble as ferric selenite (Figure 4). Se can also form organic complexes that are generally not available to plants. Se may occur in soils in a number of oxidation states depending on soil redox potential, soil $\mathrm{pH}$, microbiological effects and the presence of other ions like phosphate and sulfate, which are often added to fertilizers [25, 29, 30]. Selenate a

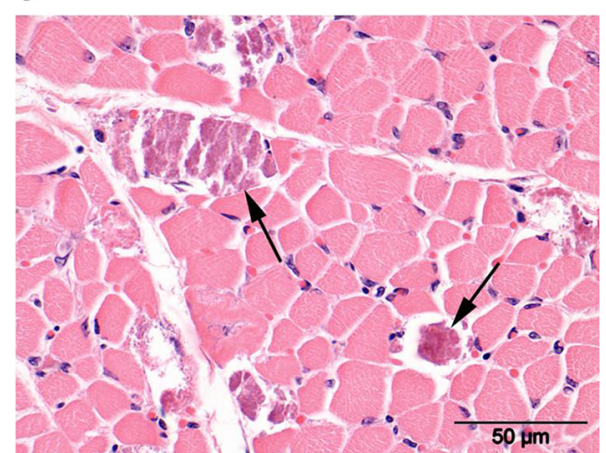

b

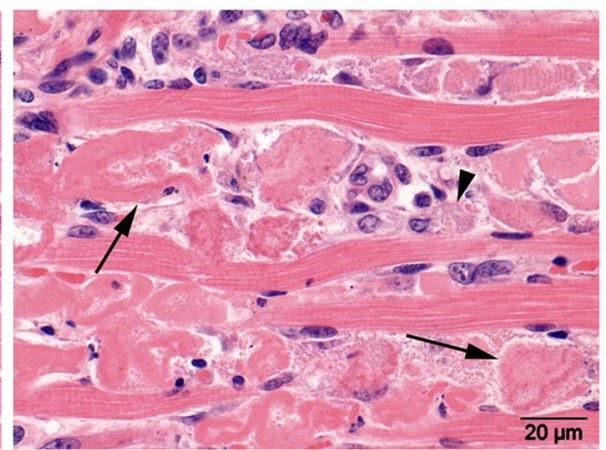

Fig. 3 Histological image of a cross section of an affected skeletal muscle showing. Panel a: multifocal mineralization of muscle fibres (arrows). H\&E stain. Panel $\mathbf{b}$ : Longitudinal section of a severely affected skeletal muscle revealing hyalinization and fragmentation of muscle fibres (arrows) and influx om macrophages phagocytizing myofibre remnants (arrowhead). H\&E stain 
Table 3 GSH-Px and Vit E values of cases 2 and 3, their respective dams and two other herd members before and after three months of supplementation of Vit $E$ and Se at premises 1

\begin{tabular}{|c|c|c|c|c|}
\hline & \multicolumn{2}{|l|}{$\mathrm{GSH}-\mathrm{Px}(\mathrm{U} / \mathrm{g} \mathrm{Hb})$} & \multicolumn{2}{|l|}{ Vitamin E ( $\mu \mathrm{mol} / \mathrm{L})$} \\
\hline & Before supplementation & After 3 months supplementation & Before supplementation & After 3 months supplementation \\
\hline Mare case 3 & 59 & 189 & 6.3 & 5.0 \\
\hline Foal case 3 & 43 & 141 & 8.7 & 6.5 \\
\hline Mare case 2 & 48 & 154 & 6.2 & 6.4 \\
\hline Horse X & 65 & 145 & 4.2 & 5.9 \\
\hline Horse $Y$ & 94 & 183 & 6.8 & 7.3 \\
\hline Reference value & \multicolumn{2}{|c|}{$120-300 \mathrm{U} / \mathrm{g} \mathrm{Hb}$} & \multicolumn{2}{|c|}{$>4 \mu \mathrm{mol} / \mathrm{L}$} \\
\hline
\end{tabular}

$\left(\mathrm{SeO}_{4}^{2-}\right)$, the ultimate oxidized form, which is also the form taken up by plants (high bio-availability), occurs only under well aerated alkaline conditions [26, 31]. However, selenate is also the most mobile form, therefore it tends to leach readily from well drained soils, that can become on their turn extremely low in Se content. When Se occurs in the less mobile selenite form, which is typical for acid or neutral soils, its availability is often hampered by absorption processes such as the binding of selenite to oxides, organic matter and clays or, precipitation as the insoluble ferric selenite in the presence of iron (Fe). Se can also form organic complexes that are generally not available to plants and that can leach from the soil. In very wet, chemical reduced soils like some peat and clay soils Se is usually present in insoluble, and thus unavailable, reduced forms (elemental or as selenides or sulfides). Recent research on Se speciation in 80 Dutch soil locations covering both grass land and arable land and covering all major soil types in the Netherlands, shows that most of the Se ( $80 \%$ on average) is present in organic forms whereas the inorganic form is mainly selenite $[32,33]$. The overall low levels of Se in Dutch soils combined with the chemical speciation of Se

Table 4 Post-supplementation GSH-Px and Vit E values of horses at premises 2. Horses with low GSH-Px had previously suffered from ragwort poisoning

\begin{tabular}{lll}
\hline & $\mathrm{GSH}-\mathrm{Px}(\mathrm{U} / \mathrm{g} \mathrm{Hb})$ & Vitamin $\mathrm{E}(\mu \mathrm{mol} / \mathrm{L})$ \\
\hline 1 & 246 & 5.1 \\
2 & 36 & 1.8 \\
3 & 65 & 1.4 \\
4 & 63 & 5.6 \\
5 & 24 & 3.8 \\
6 & 154 & 3.5 \\
7 & 254 & 5.5 \\
8 & 31 & 2.6 \\
9 & 26 & 4.0 \\
10 & 43 & 1.8 \\
Reference value & $120-300 \mathrm{U} / \mathrm{g} \mathrm{Hb}$ & $>4 \mu \mathrm{mol} / \mathrm{L}$ \\
\hline
\end{tabular}

can lead to very low bio-availability of Se in many areas in the Netherlands. And this seems to be a general trend, also in other countries.

The presence of sulfate $\left(\mathrm{SO}_{4}^{2-}\right)$ (present in certain fertilizers) inhibits the uptake of Se by plants and has a greater effect on the preferential selenate than on selenite. It was believed that a high content of phosphorus in the soil should increase Se uptake by plants as the phosphate $\left(\mathrm{PO}_{4}{ }^{3-}\right)$ ion can readily be adsorbed in soils and can displace selenite from fixation sites. However, a recent study performed in the Netherlands, indicates that both $\mathrm{SO}_{4}^{2-}$ and $\mathrm{PO}_{4}^{3-}$ can also have a negative effect on Se uptake by plants [32]. A very complete overview of Se deficiency and toxicity in animals and the role of soil and plant Se content is provided by Fordyce et al. [26].

It is clear that many factors have their influence on Se bioavailability and thus proper management with respect to Se supplementation is quite challenging. Still, there are quite some tips that can help to support implementation of an effective Se supplementation management.

In horses, focus needs to be directed towards Se status of the dam, since the Se status of the neonatal foal depends on placental passage and thus the dams Se status during gestation. The dams milk is low in Se and is not considered as an important Se source for the foal [23].

Table 5 Mineral analysis of grass and hay premises 2

\begin{tabular}{llll}
\hline & Grass & Hay & Reference values \\
\hline $\mathrm{Co}(\mu \mathrm{g} / \mathrm{kg} D M)$ & 89 & 88 & $>100$ \\
$\mathrm{Na}(\mathrm{g} / \mathrm{kg} D M)$ & 1.6 & 2.7 & $3.0-30$ \\
$\mathrm{Mg}(\mathrm{g} / \mathrm{kg} \mathrm{DM})$ & 2 & 2.2 & $3.9-5.0$ \\
$\mathrm{Se}(\mu \mathrm{g} / \mathrm{kg}$ DM) & 29 & 44 & $100-1000$ \\
$\mathrm{Fe}(\mathrm{mg} / \mathrm{kg} \mathrm{DM})$ & 117 & 175 & $50-100$ \\
$\mathrm{Ca}(\mathrm{g} / \mathrm{kg} \mathrm{DM})$ & 4.1 & 3.0 & $2-7$ \\
$\mathrm{P}(\mathrm{g} / \mathrm{kg} \mathrm{DM})$ & 3 & 3.0 & $2-5$ \\
$\mathrm{~K}(\mathrm{~g} / \mathrm{kg} D M)$ & 17 & 10 & $>4.3$ \\
$\mathrm{Cu}(\mathrm{mg} / \mathrm{kg} \mathrm{DM})$ & 8.5 & 7.8 & $7.0-10$ \\
$\mathrm{Zn}(\mathrm{mg} / \mathrm{kg} \mathrm{DM})$ & 46 & 39 & $40-100$ \\
$\mathrm{Mn}(\mathrm{mg} / \mathrm{kg} \mathrm{DM})$ & 223 & 348 & $>40$ \\
\hline
\end{tabular}




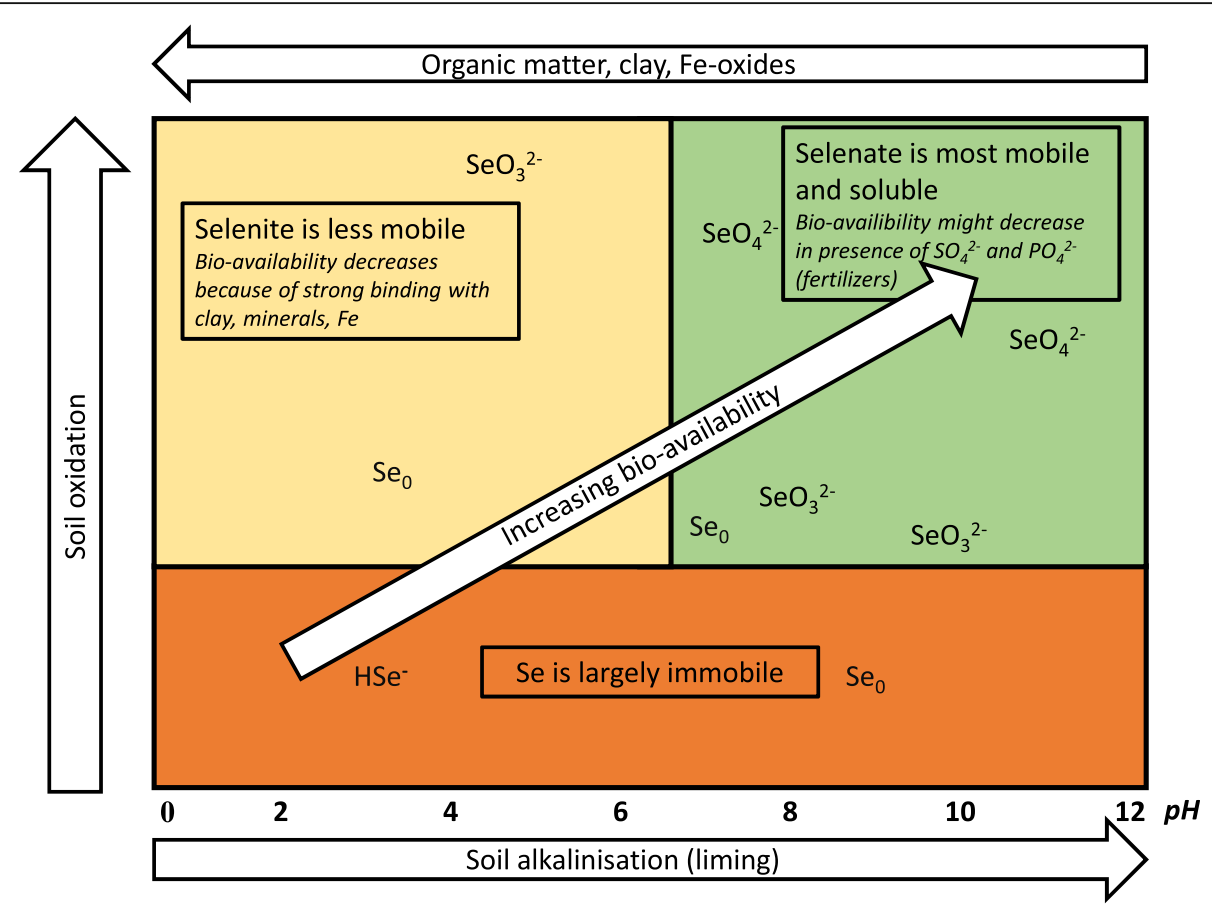

Fig. 4 Schematic overview illustrating the influence of specific soil features such as pH on chemical behaviour and bio-availability of Se. Notice that the highly bio-available selenate is also most soluble and will therefore easily leach from well-drained soils. (Adapted from Fordyce [26])

This emphasizes the importance of soil analysis for grazing meadows, for pastures with roughage production and for parcels intended for fodder crop production as well as the analysis of roughage being fed to broodmares. Soils must be strategically managed in order to achieve an optimal fertility status for at least $\mathrm{pH}$, organic matter and phosphate content, which in turn will stimulate appropriate Se-uptake by the crops. Figure 1 (panel a) shows the total top soil Se concentration in the Netherlands measured with ICP-MS after HFdestruction and for comparison, in panel B the potentially reactive ("available") Se concentration in top soil $(0-20 \mathrm{~cm})$ samples is depicted [34]. Comparison of the two maps shows clearly that only part of the Se present in Dutch soils is actually available for uptake by plants, and that the maximum available levels in a large part of the country are too low for healthy Se levels in crops. A similar trend is seen in Belgium, as depicted in Fig. 2. Panel a, shows the map with the acid extractable contents of Se in the top soil $(0-6 \mathrm{~cm})$ of 117 pastures in Flanders (Belgium) between 2007 and 2015, measured with ICP-MS after extraction with $\mathrm{HNO}_{3}-\mathrm{HCl}$ (1:3). Both Figures clearly demonstrate that both in Flanders as well as in the Netherlands the Se content of the upper soil ranges in most cases around the background values of 0.2 to $0.5 \mathrm{ppm}$, as was also determined by De Temmerman et al. [35].

When Se-content in soil is lower than $0.6 \mathrm{ppm}$ there is a clear risk for having deficient Se content in the grass or roughage produced on these soils and an inadequate Se uptake by livestock living and being fed fodder crops harvested on these grounds. A balanced soil fertility status stimulates the Se-uptake by the crop, and to reach this balanced fertility status, a near-neutral $\mathrm{pH}$ as well as a high phosphate content of the soil are beneficial. Figure 2, panels $\mathrm{a}, \mathrm{b}$ and $\mathrm{c}$ show the soil fertility status of 117 pastures analysed by the Soil Service of Belgium on demand of the Flemish farmers. The soil fertility condition is classified in 7 classes: very low, low, rather low, normal (target value), rather high, high and very high. In most pastures the $\mathrm{pH}$ is within the target value or even more alkaline which increases the Se-availability together with the rather low organic matter content. About 16.5\% of the pastures has a phosphate content within the target value and $58.8 \%$ above the target value, which stimulates the Se-uptake by the crop. Still, several regions are low in Se content (panel A). In cases where soil analysis reveals a Se-content $<0.6 \mathrm{ppm}$, Se fertilization is recommended, together with correction of soil $\mathrm{pH}$ if needed. For grassland a fertilization of $2-4 \mathrm{~g} \mathrm{Se} / \mathrm{ha}$ is recommended for every grass cut with a maximum of $10 \mathrm{~g} \mathrm{Se} /$ ha/year [36], a level of fertilization found in many countries, including the Netherlands [37]. The effect of Se fertilization can be evaluated by follow-up analysis of the Se content in the grass or roughage, since Se can potentially be toxic in case of excessive supplementation, either through the crops or as a result of leaching to ground and surface waters (because the mobile selenate 
form is mostly used for supplementation). In Finland and some other countries Se fertilization proved effective in increasing the Se levels in crops, animals and humans [38].

Possible interventions at soil management level mainly involve the choice of fertilizer. Some rock phosphate fertilizers are rich in Se, and in most countries where Se is permitted as a supplement to fertilizers, farmers can buy all kinds of fertilizers with added Se. Once, Se fertilization is applied, proper follow-up of the resulting Se soil and crop content should be performed to check whether additional oral supplementation of livestock is necessary. Oral supplementation can be achieved by applying top dressings on the feed, providing concentrates fortified with Se or by providing the animals with Seenriched lick stones (although the latter approach entails thatthe uptake will greatly depend on the individual licking preference of the horse). Both inorganic Se (selenite) and organic Se (Se-enriched yeasts) supplements can be used to increase the Se status [39]. However, organic Se seems to have a higher digestibility [40] and be more effective to elevate total plasma Se because of higher selenomethionine levels [41]. Proteins incorporated with selenomethionine might serve as future Se reserve and explain why GSH-Px activity remains increased for a longer period after withdrawal of an organic Se supplement when compared to an inorganic Se supplement [42].

As mentioned previously, problems associated with Se deficiency are expected to occur with increasing prevalence. In the current presented case series, the most consistent clinical symptoms were muscular weakness, inadequate suckle reflexe and stillbirth, as reported in literature [6]. Clinical biochemistry showed severely increased serum muscle enzymes and low GSH-pX values. No direct measurement of blood Se levels was performed, however several authors have confirmed the strong correlation between blood Se and GSH-pX levels in both foals and horses [23, 43, 44]. The differential diagnosis for elevated muscle enzymes in foals includes in utero hypoxia (e.g. due to Equine Herpes Virus, placentitis), dystocia (peripartum asphyxia and muscle trauma) and hereditary myopathies (typical but not limited to Quarter Horses and related breeds) [45-47]. Both in utero hypoxia and dystocia are typically not associated with the extreme increases in muscle enzyme levels encountered in the current case series ( $>100$-fold increase above reference range, except for case 3), in association with low GSH-Px levels [46, 48]. Regarding the hereditary myopathies, PSSM (polysaccharide storage myopathy) is typical for adult horses after the onset of training [45]. To our knowledge, the youngest foal described with CPK elevations due to PSSM was 1 month old and did not have any clinical signs yet [49]. GBED (glycogen branching enzyme deficiency) is fatal in all cases within the first two months after birth. Postmortem macroscopic and histological signs are limited without the use of PAS staining, which is not in accordance to our findings in the two non-surviving cases [45].

Important to notice is that both in this study and in others, Se deficiency is more consistently present in WMD cases than is Vit E deficiency [1,9]. Indeed, in our study, the Vit E status in all foals but one with WMD was normal. This was also true for the respective mares in which Vit E and GSH-pX was determined. It may be that Se deficiency is more likely to trigger muscular necrosis, whereas Vit E deficiency may be more related to fat necrosis [50].

Finally, an interesting finding in the current study was the fact that proper Se supplementation was ineffective to solve problems at one premises formerly diagnosed with ragworth poisoning. Here, foals suffering from WMD were still being born despite supplementing the dams with Vit $\mathrm{E}$ and Se for a prolonged period. All these post-supplementation WMD affected foals were born out of mares that one year before, had been diagnosed with ragwort poisoning. They still showed an insufficient Se status despite supplementation, probably due to a diminished liver function, although no disturbed blood liver enzymes were present anymore. The findings in our case series could warrant for a more thorough follow-up of Se status when supplementing Se to Se deficient horses suspected of having a reduced liver function. Although up until now, no equine study has investigated a possible link between reduced hepatic function (due to ragwort poisoning) and birth of Se depleted foals, a link between Se deficiency and liver disease is well-known in human medicine [51, 52]. Recently, Burk et al. [53] have demonstrated that in Sedeficient human patients with liver cirrhosis the selenomethionine metabolism is impaired and therefore organic Se (selenomethionine) supplementation is not effective, in contrast to inorganic Se (selenate) which does increase GSH-Px activity. However, in the current case series inorganic selenium (selenite) was supplemented and this could not increase GSH-Px activity either. It would be interesting to check in the future whether increased doses of inorganic selenium or perhaps another form of inorganic selenium (selenate instead of selenite) can offer a solution in such a situation.

\section{Conclusions}

In order to prevent foals being born with White Muscle Disease in premises localized in areas with low Se soil content, routine soil Se content monitoring, together with analysis of the roughage fed to broodmares is recommended. As the uptake of Se by the crop is not only depending on the Se content of the soil but is also 
influenced by the general soil fertility condition especially soil $\mathrm{pH}$, phosphate and organic matter content, a complete soil fertility analysis of the top soil is recommended every four years. Addtionally, monitoring Se status of broodmares and their herdmates (plama GSH$\mathrm{Px}$, serum/plasma/whole blood Se) is advisable in Se deficient regions. For the remediation of Se deficiency in animals various options are available, indirectly by improving the Se status of the soil by applying specialized fertilizers and directly by supplementing the intake of the animals through their feedstuffs. Structurally improving the Se status of the soil is generally the prefered choice in the long run [54]. Special consideration needs to be taken in broodmares suspected of having a reduced liver function, as the Se status may remain low despite oral Se supplementation.

\section{Manufacturers' details}

1. Amikacin ${ }^{\circ}$, Merial, Velserbroek, the Netherlands AST farma BV, Oudewater, the Netherlands

2. Ampi-Dry ${ }^{\circ}$, Dopharma, Raamsdonksveer, The Netherlands

3. Metacam ${ }^{\circ}$, Boehringer Ingelheim, Alkmaar, The Netherlands

4. Gastrogard ${ }^{\circ}$, Merck Schuchardt OHG, Hohenbrunn, Germany

5. Etosol ${ }^{\circ}$, Eurovet Animal Health BV, Bladel, the Netherlands

6. Professional's Choice Supplements ${ }^{\circ}$, WD Holdings, London, United Kingdom

\section{Abbreviations}

CPK: creatine phosphokinase; Fe: iron; GSH-Px: glutathione peroxidase; LDH: serum lactate dehydrogenase; Se: selenium; SGOT: serum glutamic oxaloacetic transaminase; Vit E: Vitamin E; WMD: white muscle disease

\section{Acknowledgements}

The authors acknowledge Jan Bries and Mia Tits of the Soil Service of Belgium for the availability of the soil fertility data and Wim Bussink of the Nutrient Management Institute for providing information on micro-nutrients in agriculture.

\section{Funding}

No funding was available to publish this retrospective case report.

\section{Availability of data and materials}

Data sharing is not applicable to this article as no datasets were generated or analysed during the current study.

\section{Authors' contributions}

$\mathrm{CD}, \mathrm{MdB}, \mathrm{SW}$ and BB: Follow up cases, performance analyses, design and writing manuscript. HV and GM: design and writing manuscript, geological maps and management advice. GG: design and writing manuscript, autopsy/ histopathology. LP and CD: review manuscript. All the authors have read and approved the article.

\section{Competing interests}

There were no competing interests involved.

\section{Consent for publication}

All owners were informed about and agreed with the use of the patient files of their animals in order to publish this retrospective case report.

\section{Ethics approval and consent to participate}

This is a retrospective case report of patients admitted to Wolvega Equine Hospital (The Netherlands) without the use of new or experimental treatments, therefore no ethics approval is available.

\section{Publisher's Note}

Springer Nature remains neutral with regard to jurisdictional claims in published maps and institutional affiliations.

\section{Author details}

${ }^{1}$ Department of Comparative Physiology and Biometrics, Faculty of Veterinary Medicine, Ghent University, Ghent, Belgium. ${ }^{2}$ Wolvega Equine Hospital, Weststellingwerf, The Netherlands. ${ }^{3}$ Department of Clinical Veterinary Science, University of Bristol, Langford House, Langford, North Somerset, UK. ${ }^{4}$ Division of Crop Biotechnics, KU Leuven and Soil Service of Belgium, Leuven, Belgium. ${ }^{5}$ Alterra, Wageningen University \& Research Centre, Wageningen, The Netherlands. ${ }^{6}$ Department of Pathobiology, Faculty of Veterinary Medicine, Utrecht University, Utrecht, The Netherlands.

Received: 1 February 2017 Accepted: 27 April 2017

Published online: 03 May 2017

References

1. Higuchi T, Ichijo S, Osame S, Ohishi H. Studies on serum selenium and tocopherol in white muscle disease of foal. Nippon Juigaku Zasshi. 1989a; 51:52-59.

2. Finno C, Valberg S. A comparative review of vitamin $E$ and associated equine disorders. J Vet Intern Med. 2012;26:1251-66.

3. Mahan D, Jones J, Cline J, Cross R, Teague H, Grifo A Jr. Efficacy of selenium and vitamin $\mathrm{E}$ injections in the prevention of white muscle disease in young swine. J Anim Sci. 1973:36:1104.

4. Allen W. New developments in muscle pathology: nutritional myopathies including "muscular dystrophy" or "white muscle disease". Vet Res Commun 1977;1:243-50.

5. Freestone JF, Carleson JP. Muscle disorders in the horse: a retrospective study. Equine Vet J. 1991;23(2):86-90.

6. Lofstedt J. White muscle disease of foals. Vet Clin North Am Equine Pract. 1997;13:169-85.

7. Gabbedy B, Masters H, Boddington E. White muscle disease of sheep and associated tissue selenium levels in Western Australia. Aust Vet J. 1977:53:482-4.

8. Hill KE, Motley AK, Li X, May JM, Burk RF. Combined selenium and vitamin E deficiency causes fatal myopathy in guinea pigs. J Nutr. 2001:131:1798.

9. Streeter R, Divers T, Mittel L, Korn A, Wakshlag J. Selenium deficiency associations with gender, breed, serum vitamin $\mathrm{E}$ and creatine kinase, clinical signs and diagnoses in horses of different age groups: a retrospective examination 1996-2011. Equine Vet J. 2012:44:31-5.

10. Ludvikova E, Jahn P, Pavlata L, Vyskocil M. Selenium and vitamin E status correlated with Myopathies of horses reared in farms in the Czech Republic Acta Vet Brno. 2005:74:377-84

11. Votion DM, Linden A, Saegeman C, et al. History and clinical features of atypical myopathy in horses in Belgium (2000-2005). J Vet Intern Med. 2007; 21(6):1380-91.

12. MacLeay JM. Diseases of the musculoskeletal system. In: Reed SM, Bayly WM, Sellon DC, editors. Equine Internal Medicine. 3rd ed. St. Louis: Saunders; 2010. p. 488-544.

13. Rotruck J, Pope A, Ganther H, Swanson A, Hafeman D, Hoekstra W. Selenium: biochemical role as a component of glutathione peroxidase. Science. 1973;179:588

14. Gabbedy B, Richards R. White muscle disease in a foal. Aust Vet J. 1970;46:111-2.

15. Katz L, O'Dwyer S, Pollock P. Nutritional muscular dystrophy in a four-dayold Connemara foal. Ir Vet J. 2009;62:119-24

16. Hoshino Y, Ichijo S, Osame S, Takahashi E. Studies on serum tocopherol, selenium levels and blood glutathione peroxidase activities in calves with white muscle disease Nippon Juigaku Zasshi. 1989;51:741-48.

17. Van Vleet JF, Valentine BA. Nutritional Myopathy. In: Maxie G, editor. Jubb, Kennedy \& Palmer's pathology of domestic animals. Edinburgh: Elsevier: 2007. p. 236-43. 
18. Gissel-Nielsen G, Gupta UC. Agronomic approaches to increase selenium in livestock feed and food crops. In: Cakmak I, Welch RM, editors. Impacts of agriculture on human health and nutrition - volume I. Paris: Eolss Publishers; 2009. p. 383-8.

19. Haug A, Graham RD, Christophersen OA, Lyons GH. How to use the world's scarce selenium resources efficiently to increase the selenium concentration in food. Microb Ecol Health Dis. 2007;19:209-28.

20. Laven RA, Nortje R. Diagnosis of the cu and se status of dairy cattle in New Zealand: how many samples are needed? N Z Vet J. 2013;61(5):269-73.

21. Waldner $\mathrm{CL}$, Blakley B. Evaluating micronutrient concentrations in liver samples from abortions, stillbirths, and neonatal and postnatal losses in beef calves. J Vet Diagnostic Investigation. 2014;26(3):376-89.

22. Karren BJ, Thorson JF, Cavinder CA, Hammer CJ, Coverdale JA. Effect of selenium supplementation and plane of nutrition on mares and their foals: selenium concentrations and glutathione peroxidase. J Anim Sci. 2010;88:991-7.

23. Lee J, McAllister E, Scholz R. Assessment of selenium status in mares and foals under practical management conditions. J. Eq. Vet. Sci. 1995;15:240-5.

24. Gay L, Kronfeld D, Grimsley-Cook A, Dascanio J, Ordakowski-Burk A, Splan R, Dunnington E, Sklan D. Retinol,[beta]-carotene and [beta]-tocopherol concentrations in mare and foal plasma and in colostrum. J Eq Vet Sci. 2004;24:115-20.

25. Allaway WH. Trace element cycling. Adv Agron. 1968;20:235-74.

26. Fordyce F. Selenium deficiency and toxicity in the Environment. In: Selinus O, Alloway B, Centeno JA, Finkelman RB, Fuge R, Lindh U, Smedley P, editors. Essentials of medical geology. Impacts of the natural Environment on public health. Amsterdam: Elsevier Academic Press; 2005. p. 373-416.

27. Traber MG, Sies H. Vitamin E in humans: demand and delivery. Annu Rev Nutr. 1996;16:321-47.

28. Wiedenfeld $\mathrm{H}$. Plants containing pyrrolizidine alkaloids: toxicity and problems. Food Additives \& Contaminants: Part A. 2011;28:282-92.

29. Baeyens J. Nutrition des plantes de culture. Université de Louvain. 1967;687 pp.

30. McBride MB. Environmental chemistry of soils. Oxford: Oxford University Press; 1994. p. 406

31. Mengel K, Kirkby EA. Principles of plant nutrition. 3rd ed. Horgen: International Potash Institute; 1982. p. 655.

32. Supriatin S, Weng L, Comans RNJ. Selenium speciation and extractability in Dutch agricultural soils. Sci Total Environ. 2015;532:368-82.

33. Weng L, Vega FA, Supriatin S, Bussink W, Riemsdijk WHV. Speciation of se and DOC in soil solution and their relation to se bioavailability. Environ Sci Technol. 2011:45:262-7.

34. Mol G, Spijker J, PFM v G, Römkens P. Geochemische bodematlas van Nederland. Wageningen: Wageningen Academic Publishers; 2012. p. 222. (Geochemical Soil Atlas of the Netherlands, in Dutch; http://www. wageningenacademic.com/doi/book/10.3920/978-90-8686-743-1).

35. De Temmerman LO, Hoenig M, Scokart PO. Determination of "normal" levels and upper limit values of trace elements in soils. Z Pflanzenernähr Bodenkd. 1984;147:687-94.

36. Jacobs LW. (Ed.) Selenium in agriculture and the Environment, soil Science Society of America Special Publication 23, SSSA, Madison, WI, USA; 1989.

37. Bussink DW, den Boer DJ, van Duinkerken G, Zom RLG, Mineralenvoorziening rundvee via Voerspoor of Bodem- en Gewasspoor, Nutrienten Management Instituut Rapport O 1139, Oosterbeek, 134 pp; 2007.

38. Eurola M. Twenty years of Selenium Fertilization. Conference Proceedings, AgriFood Research report 69, MTT Agrifood Research Finland, Helsinki, pp 108; 2005.

39. Richardson SM, Siciliano PD, Engle TE, Larson CK, Ward TL. Effect of selenium supplementation and source on the selenium status of horses. J Anim Sci. 2006;84:1742-8.

40. Pagan JD, Karnezos P, Kennedy MAP, Currier T, Hoekstra KE. Effect of Selenium source on Selenium digestibility and retention in exercised Thoroughbreds. In: Proc. 16 ${ }^{\text {th }}$ Equine Nutr. And Physiol. Soc. Symp. 2011 p. 135-140.

41. Calamari L, Ferrari A, Bertin G. Effect of selenium source and dose on selenium status of mature horses12. J Anim Sci. 2009;87:167-78.

42. Calamari L, Capelli P, Ferrari A, Bertin G. Gluthathione peroxidase responses in mature horses following the withdrawal of an organic selenium supplement. Ital J Anim Sci. 2007;6(sup 1):275-7.

43. Ludvikova E, Pavlata L, Vyskocil M, Jahn P. Selenium status of horses in the Czech Republic. Acta Vet. Brno. 2005;74:369-75.

44. Brummer M, Hayes S, Dawson KA, Lawrence LM. Measures of antioxidant status of the horse in response to selenium depletion and repletion. J Anim Sci. 2013;91:2158-68.
45. Valberg SJ. A review of the diagnosis and treatment of Rhabdomyolysis in foals. AAEP Proceedings. 2002;48:117-21.

46. Axon JE, Palmer JE. Clincal pathology of the foal. Vet Clin Equine. 2008;24:357-85.

47. Morresey PR. Assessing the weak foal. In: Proceedings of the American Association of Equine Practitioners Focus on the first year of life; 2014. p. 10-5.

48. Chiba A, Aoki T, Itoh M, Yamagishi N, Shibano K. Hematological and blood biochemical characteristics of newborn heavy draft foals after Dystocia. J Equine Vet Sci. 2017;50:69-75.

49. Corte FD, Valberg SJ, MacLeay JM, Mickelson JR. Developmental onset of polysaccharide storage myopathy in 4 quarter horse foals. J Vet Intern Med. 2002;16:581-7.

50. Bruijn de CM. Veldhuis Kroeze EJB, Sloet van Oldruitenborgh-Oosterbaan M. Yellow fat disease in equids. Equine Vet Educ. 2006;18:38-44.

51. Czuczejko J, Zachara BA, Staubach-Topczewska E, Halota W, Kedziora J. Selenium, glutathione and glutathione peroxidases in blood of patients with chronic liver diseases. Acta Biochim Pol. 2003;50:1147-54.

52. Czeczot H, Scibior D, Skrzyki M, Podsiad M. Glutathione and GSH-dependent enzymes in patients with liver cirrhosis and hepatocellular carcinoma. Acta Biochim Poo. 2006;53:237-42

53. Burk RF, Hill KE, Motley AK, Byrne DW, Norsworthy BK. Selenium deficiency occurs in some patients with moderate-to-severe cirrhosis and can be corrected by administration of selenate but not selenomethionine: a randomized controlled trial. Am J Clin Nutr. 2015;102:1126-33.

54. Ros GH, van Rotterdam AMD, Doppenberg GD, Bussink DW, Bindraban PS Se Fertilization: An Agro-Ecosystem Approach. VFRC Report 2014/3. Virtual Fertilizer Research Center, Washington DC. 2014 pp 62.

55. Brinsko SP, Blanchard TL, Varner DD, Schumacher J, Love CC, Hinrichs K, Hartman DL. CHAPTER 9 - Management of the Pregnant Mare. In: Brinsko SP, Blanchard TL, Varner DD, Schumacher J, Love CC, Hinrichs K, Hartman $\mathrm{DL}$, editors. Manual of equine reproduction. 3rd ed. Maryland Heights, Mosby Elsevier; 2011. p. 114-30.

56. Carlson GP. Clinical chemistry tests. In: Smith BP, editor. Large Animal Internal Medicine. 4th ed. St. Louis: Mosby Elsevier; 2008. p. 375-97.

\section{Submit your next manuscript to BioMed Central and we will help you at every step:}

- We accept pre-submission inquiries

- Our selector tool helps you to find the most relevant journal

- We provide round the clock customer support

- Convenient online submission

- Thorough peer review

- Inclusion in PubMed and all major indexing services

- Maximum visibility for your research

Submit your manuscript at www.biomedcentral.com/submit

) Biomed Central 